\title{
THEORETICAL ASPECTS OF CULTURAL ECONOMICS CONCEPT
}

\author{
Viktorija SKVARCIANY(i), Kristina ASTIKE் (i)* \\ Department of Economics Engineering, Faculty of Business Management, \\ Vilnius Gediminas Technical University, Sauletekio al. 11, LT-10223 Vilnius, Lithuania
}

Received 28 February 2021; accepted 01 April 2021

\begin{abstract}
Purpose - the aim of the article is to present the concept of cultural economics upon analysing the scientific literature and to single out the factors that influence the development of cultural economics.

Research methodology - analysis and synthesis of scientific literature. The articles published in CA WoS were analysed in order to extract high-quality information on the topic of cultural economics.

Findings - after analysis of the scientific literature, the factors of cultural economics have been determined. They are as follows: creativity; new technologies; consumer society; public authorities; artistic forms; media, information, digitisation; local cultural identity; public sector approach to culture; theatre, cinema, museums, crafts; media, social networks; the needs for a consumer society and culture; public sector funding for culture.

Research limitations - the main limitation of the current research is that the factors of cultural economics are distinguished from the scientific literature. For more precise identification, the experts should be interviewed as well.

Practical implications - the distinguished factors could be used for measurement of the level of a country's cultural economics level.

Originality/Value - the article summarises the cultural and economic factors of cultural economics and proposes a new concept of cultural economics.
\end{abstract}

Keywords: cultural economics, economics, culture, creativity, technology.

JEL Classification: Z10.

Conference topic: Contemporary Issues in Economics Engineering.

\section{Introduction}

In the face of globalisation processes, with the ever-increasing consumerism trends in society, the consumption of culturally produced products has increased significantly, and more and more attention is being paid to the impact of these products on national economies (Barrado-Timón et al., 2020; Gao et al., 2020). The cultural sector creates new jobs, contributes to the country's reputation, attracts foreign investment, and performs an important social function that undoubtedly creates economic value. However, in most cases, the value created by culture is not easy to directly define and measure, as culture itself is a complex and cross-sectoral phenomenon (Houkamau \& Sibley, 2019). High-quality permanent cultural services also have a positive impact on the quality of life of a society, influence the region's attractiveness for investment, and promotes tourism. All these aspects are important from an economic point of view, so cultural economics is gaining an important role in economics as a whole. The authors studying cultural economics discuss how the income received by various cultural institutions influences the economy of the region in question (Wu et al., 2019). They distinguish the factors that influence the attractiveness of different cultural institutions for visitors, and analyse the consumers' opinions of cultural economics products, evaluating the chosen cultural product or service. The authors research the influence of culture on the attractiveness of the region, attracting foreign investment, developing tourism, and evaluate the attitude of local government to cultural economics, analyse the allocation of government funding to culture (Barrado-Timón et al., 2020; Karimzadi, 2019; Roberts \& Townsend, 2016; Wiśniewska et al., 2020). However, all these cultural economics studies are fragmentary, and no unified concept of cultural economics is proposed. Thus, it is crucial to examine the proposed concepts of cultural economics and,

\footnotetext{
*E-mail: kristina.astike@vilniustech.lt
} 
upon generalisation to present the concept of cultural economics, which in turn will help to start a broader study of cultural economics. In order to better understand the concept of cultural economics, it does not suffice to present its definitions in the scientific literature; it is essential to single out the factors that influence the development of cultural economics, as they affect the development of new cultural economics services and products, thus creating added value. In addition, identifying the factors will help to develop the newly created goods and services and, as a result, increasing the country's popularity (which allows increasing the volume of tourists) and contributing to the country's economic growth.

It is essential to mention that in the face of the challenges of the Covid-19 pandemic, all sectors of the economy have been affected, the cultural economics not being an exception. Cultural economics, whose consumption of products depends directly on live contact and mobility, has also faced new challenges in surviving the pandemic. Due to the high flow of visitors, cultural institutions, such as theatres, cinemas, museums, galleries, concert halls, were among the first to be forced to close indefinitely during the pandemic. All these facts lead to the unanimous conclusion that cultural economics has suffered and continues to suffer huge losses during the pandemic. Therefore, it is important to develop this field of research by finding new ways to help establish cultural economics.

Thus, the aim of this article is to examine how the concept of cultural economics is presented in the scientific literature and to present a theoretical model that would summarise the factors influencing the development of cultural economics. The objective of current research is cultural economics.

The article consists of three parts: introduction, main body, conclusions. The main body is divided into two parts. The first part of this article will provide a generalised concept of cultural economics. The second part will review the factors that influence cultural economics.

\section{Concept of cultural economics}

The concept of cultural economics is studied in works by scientists from various fields: culture, economics, psychology, sociology, management, etc. The reason for this being that the field of cultural economics research is extensive, covering many areas of life. Cultural economics is an interdisciplinary field of scientific research, so it is important to describe the concepts of culture and economics as separate terms before examining its concept. Most authors agree that culture can be perceived in different and very broad ways, depending on the object in question. Bennett (2015) identifies culture as a way of life-based on a peculiar intellectual and political attitude. Similar opinions are held by Anderson (2020), according to whom culture is a way of life, based on knowledge, faith, and moral principles. Pauliukevičiūtė and Jucevičius (2018) offer to perceive culture even more broadly, i.e. as a social system encompassing everything that man creates or could create. In other words, the concept of culture also intervenes in the development of innovations based on the latest technologies and their development in society. Another, more traditional, approach to culture is the description of culture as a society bound by common ethnic identities such as language, religion, customs (Dupré, 2018). This approach presupposes the understanding of culture as the identity of a society or a region, the development of which is directly related to the development of culture itself. From the presented descriptions, it can be seen that the definitions of culture are dominated by human intelligence, ethnic characteristics and the individual behaviour based on it, which influences the way of life of society and the region. Thus, summarising the given definitions of culture, it can be said that culture is perceived as a whole created by the physical and intellectual work of human society, which includes knowledge, faith, art, morality, laws and customs. Definitions of economics will be provided below in order to combine the two analysed concepts later.

Traditionally, the term economics has been understood in the scientific literature as the unified system of a particular economy and the processes that take place in it that are influenced by the aspects of the behaviour of human society (Mongin, 2006). The modern description of economics also focuses on aspects of human society's behaviour, wishes, desires, and how to implement them with limited resources and opportunities (Marco-Serrano et al., 2014). Thus, in this article, economics is understood and analysed precisely through the behavioural aspects of human society, when the aim is to fulfil one's desires with limited resources.

From the presented descriptions of culture and economics, it can be seen that both of these fields of science analyse human society, its behaviour, influencing certain choices of people. This leads to the conclusion that these areas of research are closely related, and the results of their research are relevant to both parties. Description of culture and economics as separate terms, it is possible to move on to the concept of cultural economics as such. Table 1 summarises the concepts of cultural economics presented by various authors.

As can be seen from Table 1, there is no consensus among the authors. Some authors tend to place more emphasis on science-based technologies in the concept of cultural economics, while others highlight artistic forms through cultural institutions. The descriptions in Table 1 show that the concept of cultural economics can be understood very broadly, so many authors in their research choose to examine cultural economics in one specific selected aspect, using various cultural statistics, and therefore develop the concept of cultural economics as such taking into consideration solely the analysed object. 
Table 1. Definitions of the cultural economics

\begin{tabular}{|l|l|}
\hline \multicolumn{1}{|c|}{ Author (year) } & \multicolumn{1}{c|}{ The concept of cultural economics } \\
\hline Karimzadi (2019) & $\begin{array}{l}\text { Cultural economics is described as economics based on intellectual property, creativity, digital } \\
\text { technologies, culture, art, entrepreneurship, design, and knowledge. }\end{array}$ \\
\hline $\begin{array}{l}\text { Barrado-Timón et al. } \\
(2020)\end{array}$ & $\begin{array}{l}\text { The concept of cultural economics should be understood as a modern field of science that is based on } \\
\text { digital technologies, the development of which is directly related to the development of technologies. }\end{array}$ \\
\hline $\begin{array}{l}\text { Wiśniewska et al. } \\
(2020)\end{array}$ & $\begin{array}{l}\text { The concept of cultural economics is presented through cultural institutions: museums, theatres and } \\
\text { cinemas by analysing their economic opportunities and how the income received by these institutions } \\
\text { contributes to the economy of the city or region in question. }\end{array}$ \\
\hline Ljunggren (2016) & $\begin{array}{l}\text { From a narrower perspective, cultural economics can be understood directly as the economic benefits of } \\
\text { products created by certain cultural groups. }\end{array}$ \\
\hline Tarnovskii (2018) & $\begin{array}{l}\text { Cultural economics could be defined as economic, legal, labour relations in the field of culture and } \\
\text { mechanisms of governmental support of culture. }\end{array}$ \\
\hline Korovnikova (2016) & Cultural economics is the field that creates the economic interface with the cultural environment. \\
\hline
\end{tabular}

An example is the concept of cultural economics, which is presented through cultural institutions (Wiśniewska et al., 2020). The authors analyse how the income of museums, theatres and cinemas differs, what indicators influence the attendance of the analysed cultural institutions and how the income of these institutions contributes to the economy of the analysed city (Warsaw). Another example analysed considers the concept of cultural economics to be a modern field of science, based on digital technologies (Barrado-Timón et al., 2020). The authors emphasise that in today's global and digital world, the concept of cultural economics must be understood as a modern field of science, based on digital technologies and how technological developments directly affect the development of the entire region. Ljunggren (2016) analyses cultural economics in yet another aspect, through the products created by cultural groups and their benefits in the region under analysis. The author singles out such cultural groups as the academic community, architects, artists, journalists and, in his research, analyses the economic and cultural benefits of the cultural capital they generate.

Upon the summary of these definitions of cultural economics, it can be concluded that cultural economics is a vast field of research, covering many areas of public activity. This also influences the attitude of researchers to the study of cultural economics and the fact that there is no unanimous opinion on the concept of cultural economics; it directly depends on the object in question. Thus, summarising the presented concepts of cultural economics, it can be stated that cultural economics is understood and analysed as the interaction of human-made activities with new technologies, various artistic forms, knowledge, and creativity.

\section{Factors affecting cultural economics}

Examining the concept of cultural economics and in order to better understand it, it is reasonable to ask what factors affect the development of cultural economics and a need to describe those rises. The scientific literature shows that one such factor is creativity (Hodgson \& Hellmanzik, 2019; Peukert, 2019; Towse, 2010). In addition, it is creativity that is mentioned in the descriptions in Table 1 as one of the main factors influencing the services and products created by cultural economics and contributing to their development.

Traditionally, creativity is understood as a new, original, innovative tool, an artistic form related to the cultural field and perceived as a precondition for the development of artistic activity (Ciurea \& Filip, 2019). Recently, however, the concept of creativity has further expanded to include various types of technical, intellectual, entrepreneurial, and other types of creativity (Bilan et al., 2019). Due to the latter approach that creativity is mentioned in the descriptions of cultural economics, and this approach makes it even more possible to link the need for creativity with the innovative functioning and development of scientific, technological, economic and cultural systems (see Figure 1).

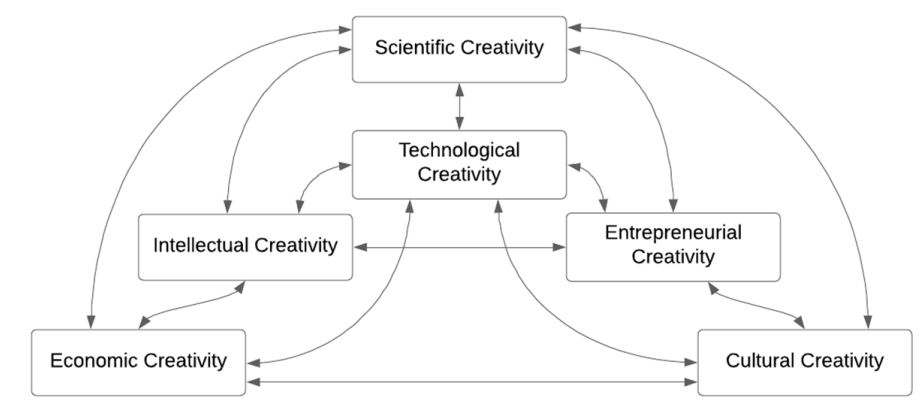

Figure 1. Interconnection of types of creativity in science, technology, culture and economics (source: created by the authors based on Ţiţan et al., 2008) 
From the presented figure (see Figure 1), a clear connection between different types of creativity in cultural, economic and technological science can be seen. The presented figure shows the intellectual type of creativity, which is related to scientific, cognitive talents and their manifestation in the creation of new and useful products in the social or other fields. It also presents a type of entrepreneurial creativity associated with the ability to think independently, non-stereotypically, generate new ideas, and apply them to business development to achieve new performance outcomes (Bilan et al., 2019). Both types of creativity mentioned are characterised by innovation and the application of originality in the creation of new and useful products that can be applied in both science and business. The obvious link between creativity and technologies, influencing the development of cultural economics, is also supported by other authors in their research. Roberts and Townsend (2016) analyse how creativity contributes to the development of culture in regions and how analysed development is reflected in different regions' economies. The authors' research identifies certain creative sectors: advertising, architecture, art, cinema, crafts, etc. and how they have developed in the regions in question since it is their development that affects the economy of the region. The fact that the development of cultural economics is directly influenced by creativity is also agreed with by Barrado-Timón et al. (2020), who argue that even countries with sizeable cultural heritage that attracts investment through tourism still need to find new creative ways to exploit it, as it is not enough to have a rich cultural heritage; it is necessary to be able to creatively employ it. According to the authors, although a large number of cultural objects in the region contributes to the regional economy, it is noticeable that sometimes it also becomes an obstacle to the development of creativity. Such paradox can be explained by relying solely on the available resources of cultural objects and the economic benefits they bring, without seeking to develop them creatively through new technologies or artistic forms, which would make the cultural object even more attractive.

According to Figure 1, it is necessary to emphasise that it is the ability to develop creativity in science that directly leads to the development of new technologies, which also affects cultural economics. In today's digitalised world, technology is a part of everyday life that creates new opportunities in many areas of activity, the economy not being an exception (Tokareva \& Vishnevskiy, 2018). Technologies influence the development of the need for new cultural services and products, increase the availability of information on various cultural content and transfer to the virtual space (Esposito \& Ricci, 2020). The latter aspect is particularly relevant for the consumption of the products and services of cultural economics during the pandemic when the live connection is severely restricted, and the consumption of services and products developed by the cultural sector would otherwise be further restricted.

Another factor influencing cultural economics is the consumer society and its need to consume the products and services created by cultural economics. It is this need of the consumer society that directly promotes the development of the output of cultural economics, and the absence of this need has the opposite effect. There is a legitimate objection that every product depends on the consumption needs of the consumer society; however, this is especially relevant for the products created by cultural economics since its products are not essential consumer goods or services. Therefore, the consumer's attitude towards these products determines the development of cultural economics, the primary function of which is not limited to profit-making, but is much broader, linked to local cultural identity. Thus, consumption not only helps to support local culture but also provides tools to support the identity, variety and diversity of local culture, as well as creates opportunities to compete in global markets and develop the local cultural economics (Patlasov, 2017).

When discussing the consumer society factor, it is important to mention that the products and services of cultural economics are developed by both the public and the private sectors. These products are relevant and useful to the population of the country or region due to the following reasons: the creation of new jobs, the increase of public employment, the attraction of investments, and the improvement of the image of the country or region. However, the creation of the mentioned products requires a lot of human resources, and society is not always able to pay for it, all the more so as these are not essential products and services (Pyykkönen \& Stavrum, 2018; Vojtíšková \& Lorencová, 2015). Given the benefits of the products and services created by cultural economics, it is the public authorities that should be interested in their development. Therefore, another paramount factor affecting cultural economics is the attitude of the public sector towards it. The public sector funding for cultural promotion should be an ongoing process; only then will the cultural impact on the country or region be long-lasting (Pauliukevičiūte \& Jucevičius, 2018; Proença, 2021). Such a public sector approach would demonstrate an understanding of the value of the state's cultural economics and its benefits to the region.

After analysing the scientific literature and singling out and describing the factors that influence cultural economics, Figure 2 presents a model of these factors.

As can be seen from Figure 2, the factors influencing cultural economics in the presented model are divided into three groups: macro, meso and micro. The first group presents the factors that are most emphasised in the scientific literature as macro-level factors: creativity, new technologies, consumer society, public authorities, public sector approach to culture, and public sector funding for culture. Creativity is interrelated with the latest technologies and influencing each other and as interdependent factors. In the first group, the interaction between consumer society and the state authorities is presented in the same way. Consumer society influences public authorities to make one deci- 


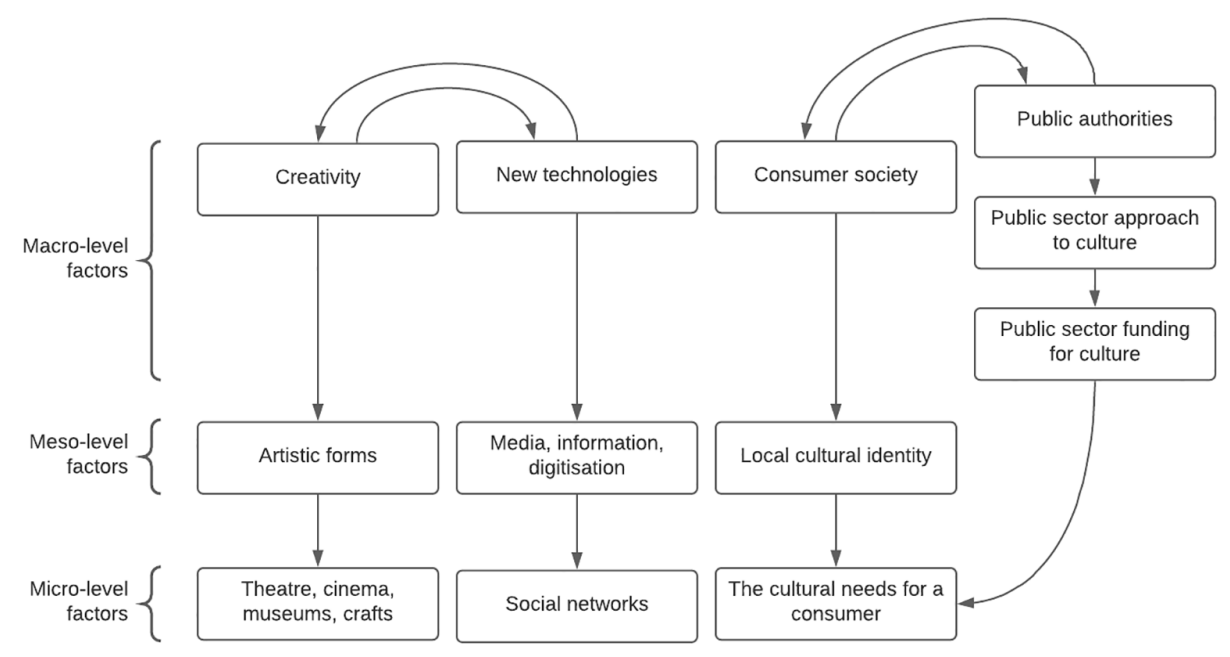

Figure 2. Factors affecting cultural economics (source: created by the authors)

sion or another, for example, decision connected with cultural events' funding. On the other hand, public authorities influence consumer society through their decisions. The second group identifies meso-level factors: art forms, media, information, digitisation, and local cultural identity. These factors are directly derived from the first-stage factors and define and flesh them out. The third group identifies the micro-level factors: theatre, cinema, museums, crafts, media, social networks, and the cultural needs of a consumer. It is these factors mentioned in the researches that analyse cultural economics that become the objects of research in order to reveal their influence on the region in question. Theatre, cinema, museums, crafts are all products of cultural economics, the consumption of which directly affects the development of cultural economics in the region. The media and social networks influence cultural economics through the popularisation and publicity of its products. The need for cultural products in the consumer society not only promotes the development of cultural economics directly but also contributes to the development of the region's identity. Public sector funding promotes the most expansive and most diverse production of cultural products, which does not always bring profits. Thus, it increases the attractiveness of the region and encourages foreign and domestic investment in the region, therefore contributing to the country's economy. Thus, summarising the developed model, it can be seen that the field of cultural economics research is vast, which is justified by the factors influencing it, and becoming the objects of studies for researchers analysing cultural economics.

\section{Conclusions}

Upon analysing the descriptions of cultural economics in the scientific literature, it was found that cultural economics is a vast field of research, covering many areas of society, and this influences the lack of a unified approach of authors to the concept of cultural economics. Some authors tend to place more emphasis on science-based technologies in the concept of cultural economics; others highlight art forms passed through cultural institutions. Thus, based on the information presented, it is clear that cultural economics is understood and analysed as human-made activities interacting with new technologies, knowledge, various art forms, and creativity.

Based on the discussed information, the factors influencing cultural economics have been singled out and divided into three levels: macro, meso, and micro. The macro-level factors are connected to the large scale, influencing entire communities, regions or even countries. These factors are creativity, new technologies, consumer society, public authorities, public sector approach to culture, public sector funding for culture. Actually, creativity could be assigned to every level, but in the current article, creativity is understood as the level of creativity of the whole country, linked to creative industries. Creativity influences the services and products created by cultural economics and contributes to their development. The same situation is with new technologies, which are understood as a general concept, i.e.new technologies, which help to modernise the workforce, develop new products, increase the availability of information with a wide range of content and transfer it to the virtual space, thus increasing the consumption of services and products created by the cultural sector;

The second level is meso-level, which is linked to a particular community (region) development in terms of cultural economics. The factors assigned to that level are artistic forms; media, information, digitisation; and local cultural identity. The first two factors could be linked to every level, but it is thought that the level of, for example, media, information and digitisation differ from region to region; hence, it would be not right to put it into the macro group and, hence, to generalise it. 
The micro-level is associated with a personal level. The factors are theatre, cinema, museum, and crafts; social networks; and cultural needs for a consumer. The first factor is analysed in terms of individual attendance of cultural events.

To sum up, it can be seen from the model of factors influencing cultural economics that the field of cultural economics research is very wide and researched. Which is justified by the factors influencing it, and becoming the objects of studies for researchers analysing cultural economics.

\section{Disclosure statement}

The authors have no competing financial, professional, or personal interests from other parties.

\section{References}

Anderson, B. (2020). Cultural geography III: The concept of "culture". Progress in Human Geography, 44(3), 608-617. https://doi.org/10.1177/0309132519856264

Barrado-Timón, D., Palacios, A., \& Hidalgo-Giralt, C. (2020). Medium and small cities, culture and the economy of culture. a review of the approach to the case of Spain in light of international scientific scholarship. Sustainability, 12(18), 7321. https://doi.org/10.3390/su12187321

Bennett, T. (2015). Cultural studies and the culture concept. Cultural Studies, 29(4), 546-568. https://doi.org/10.1080/09502386.2014.1000605

Bilan, Y., Vasilyeva, T., Kryklii, O., \& Shilimbetova, G. (2019). The creative industry as a factor in the development of the economy: Dissemination of European experience in the countries with economies in transition. Creativity Studies, 12(1), 75-101. https://doi.org/10.3846/cs.2019.7453

Ciurea, C., \& Filip, F. G. (2019). The globalization impact on creative industries and cultural heritage: A case study. Creativity Studies, 12(2), 211-223. https://doi.org/10.3846/cs.2019.7753

Dupré, J. F. (2018). Operationalizing cultural citizenship: towards a concept of culture regime. Citizenship Studies, 22(3), 329-343. https://doi.org/10.1080/13621025.2018.1449810

Esposito, P., \& Ricci, P. (2020). Cultural organizations, digital Corporate Social Responsibility and stakeholder engagement in virtual museums: a multiple case study. How digitization is influencing the attitude toward CSR. Corporate Social Responsibility and Environmental Management, 28(2), 953-964. https://oi.org/10.1002/csr.2074

Gao, W., Ji, L., Liu, Y., \& Sun, Q. (2020). Branding cultural products in international markets: A study of Hollywood movies in China. Journal of Marketing, 84(3), 86-105. https://doi.org/10.1177/0022242920912704

Hodgson, D. J., \& Hellmanzik, C. (2019). Relationships between artistic movements and careers of modern artists: evidence from hedonic regressions with auction data. Journal of Cultural Economics, 43(2), 309-337. https://doi.org/10.1007/s10824-019-09343-6

Houkamau, C. A., \& Sibley, C. G. (2019). The role of culture and identity for economic values: a quantitative study of Māori attitudes. Journal of the Royal Society of New Zealand, 49(Supp1), 118-136. https://doi.org/10.1080/03036758.2019.1650782

Karimzadi, S. (2019). Culture in economics. Advances in Economics and Business, 7(1), 39-54. https://doi.org/10.13189/aeb.2019.070105

Korovnikova, N. A. (2016). Ekonomika kul'tury: k opredeleniju problemnogo polja. Rossija: Tendencii i Perspektivy Razvitija, $11(2), 624-626$.

Ljunggren, J. (2016). Economic rewards in the cultural upper class: The impact of social origin on income within the Norwegian field of culture. Poetics, 57, 14-26. https://doi.org/10.1016/j.poetic.2016.05.003

Marco-Serrano, F., Rausell-Koster, P., \& Abeledo-Sanchis, R. (2014). Economic development and the creative industries: A tale of causality. Creative Industries Journal, 7(2), 81-91. https://doi.org/10.1080/17510694.2014.958383

Mongin, P. (2006). A concept of progress for normative economics. Economics and Philosophy, 22(1), 19-54. https://doi.org/10.1017/S0266267105000696

Patlasov, O. Y. (2017). Civilization Pyramid transformation: From economy of consumption to social, cultural and environmental priorities. International Journal of Ecology and Development, 32(3), 86-96. http://omga-info.ru/upload/departments/kmr/patlasov/P9-Civilian-16.pdf

Pauliukevičiūtè, A., \& Jucevičius, R. (2018). Kūrybiškas vystymas kaip sumanumo dimensija kultūros vadyboje: kriterijų ir indikatoriu sistema. Public Policy and Administration, 17(1), 99-113. https://www.researchgate.net/publication/324757787_Creative_Development_as_Smartness_Dimension_in_Cultural_Management_Criterias_and_Indicators_System

Peukert, C. (2019). The next wave of digital technological change and the cultural industries. Journal of Cultural Economics, 43(2), 189-210. https://doi.org/10.1007/s10824-018-9336-2

Proença, J. J. C. (2021). Strategy, processes, culture, and funding the groundwork for sustainable innovation. Journal on Innovation and Sustainability RISUS, 11(4), 88-100. https://doi.org/10.23925/2179-3565.2020v11i4p88-100

Pyykkönen, M., \& Stavrum, H. (2018). Enterprising culture: Discourses on entrepreneurship in Nordic cultural policy. Journal of Arts Management Law and Society, 48(2), 108-121. https://doi.org/10.1080/10632921.2017.1391726

Roberts, E., \& Townsend, L. (2016). The contribution of the creative economy to the resilience of rural communities: Exploring cultural and digital capital. Sociologia Ruralis, 56(2), 197-219. https://doi.org/10.1111/soru.12075 
Tarnovskii, V. V. (2018). Economy of culture and culture of economy: institutional aspect. Proceedings of the Voronezh State University of Engineering Technologies, 79(4), 237-243. https://doi.org/10.20914/2310-1202-2017-4-237-243

Ţițan, E., Voineagu, V., \& Todose, M. (2008). The impact of cultural-creative industries on the economic growth - a quantitative approach. Annals of the University of Oradea: Economic Science, 2(1), 930-935. https://ideas.repec.org/a/ora/journl/v2y2008i1p930-935.html

Tokareva, M. S., Vishnevskiy, K. O., \& Chikhun, L. P. (2018) The impact of the Internet of Things technologies on economy. Business Informatics, 3(45), 62-78. https://doi.org/10.17323/1998-0663.2018.3.62.78

Towse, R. (2010). Creativity, copyright and the creative industries paradigm. KYKLOS, 63(3), 461-478. https://doi.org/10.1111/j.1467-6435.2010.00483.x

Vojtíšková, K., \& Lorencová, R. (2015). Public funding of culture in the Czech Republic since the fall of the iron curtain: contemporary dilemmas. International Journal of Cultural Policy, 21(5), 529-553. https://doi.org/10.1080/10286632.2014.931380

Wiśniewska, A., Budziński, W., \& Czajkowski, M. (2020). An economic valuation of access to cultural institutions: museums, theatres, and cinemas. Journal of Cultural Economics, 44(4), 563-587. https://doi.org/10.1007/s10824-020-09375-3

Wu, J., Jiang, K., \& Yuan, C. (2019). Determinants of demand for traditional Chinese opera. Empirical Economics, 57(6), 21292148. https://doi.org/10.1007/s00181-018-1531-7 